\title{
A shift in the paradigm of energy cooperation between Russia and Northeast Asia countries facing new global and regional challenges: from predominant sale of energy resources to innovation and technology cooperation
}

\author{
Boris Saneev*, Alexander Sokolov, Anatoly Lagerev, Sergei Popov, Irina Ivanova, \\ Alexander Izbuldin, Anatoly Korneyev, Svetlana Muzychuk, and Dmitry Sokolov \\ Melentiev Energy Systems Institute of Siberian Branch of the Russian Academy of Sciences, 130, \\ Lermontov str., Irkutsk, 664033, Russia
}

\begin{abstract}
The paper is concerned with the specific features of Russia's economic development in a new economic environment that caused the need to revise the priorities of energy policy. The research presents the initial conditions, targets and strategic directions of energy development in the East of the country. The focus is made on the priority lines of innovation and technology cooperation between Russia and Northeast Asian countries in the field of energy, and recommendations on necessary conditions and initiatives for their successful implementation are given.

Key words: East Siberia, the Far East, Eastern energy policy, energy sector, energy cooperation interstate innovative-technological cooperation in the energy field, mechanisms of energy strategy implementation.
\end{abstract}

\section{Eastern vector - priority line in the energy development of Russia in the first half of the 21st century (main concepts)}

Specific features of Russian economic development in a new economic environment caused the need to revise earlier adopted priorities in the economic and energy policy of the country.

The national interests of Russia require intensification of mutually beneficial energy cooperation between Russia and China, Japan, Korea and other countries of East and Northeast Asia ${ }^{1}$.

In the official documents, this priority direction in the energy development of the country was named "Eastern Vector of Russia's energy policy" [1,2]. The idea of this direction can be briefly formulated as follows:

\footnotetext{
* Corresponding author: saneev@isem.irk.ru

${ }^{1}$ According to the publications and some official documents of Japan, China and the Republic of Korea, the Northeast Asian countries include Mongolia, China, North Korea, South Korea, and Japan
} 
- $\quad$ creation of new energy centers in the East of the country ${ }^{2}$ will increase energy security of Russia, restore and strengthen energy ties among the regions, solve many crucial federal, interregional and regional problems;

creation of a wide energy infrastructure including interstate gas and oil pipelines, and transmission lines in the east of Russia and Northeast Asia will reduce the cost of energy, improve reliability of energy supply to consumers in different countries, and help solve the environmental problems.

Eastern energy policy of Russia being part of the economic policy is not an end in itself but a tool for solving many principally important federal, interregional and regional problems;

\section{Socioeconomic and geopolitical objectives:}

- social - to increase comfort and improve living conditions of the population in the eastern regions of Russia.

- economic - to enhance the efficiency of the economy of Russia's East and its competitiveness, increase the availability of resources and accessibility of territories, expand active economic space of Russia, create conditions for attraction of foreign capital and advanced technologies;

- political - to consolidate and integrate entities of Federation, strengthen the unity of economic and energy space of the country;

- geopolitical - to strengthen Russia's position in the world economic system and in the community of states in Central and Northeast Asia.

\section{Energy objectives:}

- to increase energy security of the country and regions;

- to increase adaptability and reliability of energy and fuel supply to consumers;

- to improve the territorial and production structure of the national energy sector, especially in the eastern regions of the country;

- to build the energy transport infrastructure in Russia's East (systems of oil and gas pipelines, and power transmission lines) and create a single energy transport space in Russia.

Eastern regions in the country - East Siberia and the Far East - with their great economic and energy potential are of paramount importance for the implementation of Russia's national interests in this strategically important region of the world.

\section{Initial conditions, targets and priority directions in the energy development of Russia's East}

East Siberia and the Far East of the Russian Federation possess a large fuel and energy potential:

The hydro power potential is estimated at $81 \%$ of that of the country. In East Siberia and the Far East there is $35 \%$ of coal, $15 \%$ of oil and $12 \%$ of natural gas proved reserves.

These regions play an important role in the production of energy resources in Russia: in 2015 the eastern regions produced $18,5 \%$ of electricity generated in the country, extracted $34,7 \%$ of coal, 12,1\% of oil, 7,2\% of natural gas and refined 10,5\% of crude oil.

Russia developed a large number of policy documents determining the strategic development of the economy and energy in the East of the country until 2030 in the context of energy cooperation between Russia and Northeast Asian countries. These documents are: "Energy Strategy of Russia until 2030" [2], "Program for Creation of Unified Gas Production, Transportation and Supply System in East Siberia and the Far East with Potential Gas Export to the Markets of China and other APR Countries" (Eastern Gas Program) [3], "Strategy of

\footnotetext{
${ }^{2}$ In the energy strategies of Russia, the East of the country includes the regions of East Siberia and the Far East
} 
Socioeconomic Development of the Far East and the Baikal region until 2025" [4], "Strategy of Socioeconomic Development of Siberia until 2020" [5], and others.

Melentiev Energy Systems Institute SB RAS made a certain contribution to the development of the Eastern energy strategy of Russia. In 2007-2014, in the framework of feasibility studies on the Energy Strategy of Russia 2030, and research ordered by the regional authorities, the Institute conducted a great amount of studies on feasibility of longterm directions of energy development of the country and its eastern regions and some entities of the Russian Federation in their territories [6-11].

The strategy of long-term energy development of East Siberia and the Far East was developed considering some initial conditions and targets, of which the most important are the following two:

1. In the coming 15-20 years, Russia will be unable to develop the untouched territories of East Siberia and the Far East. Therefore, it is necessary to preserve and strengthen the base for the future development.

This can be done through the so called strategic scenario of economic development of these regions.

The strategic scenario of the economic development of the eastern regions suggests that the economy of Russia and its eastern regions should quantitatively and qualitatively near the current average European level. In doing so, the rates of the economic growth in the considered regions should be higher than on average in Russia. An increase in the share of these regions in the total population number of the country is also planned.

2. Energy development in East Siberia and the Far East in the considered time horizon will be aimed at both meeting the domestic demand for energy carriers and exporting Russian energy resources to the energy markets of NEA countries.

An analysis of the situation in the energy markets of China, Korea, Japan and other countries of Northeast and Eastern Asia shows that there a niche for the Russian energy resources in these countries. Russia is ready to provide these countries on mutually acceptable terms with the following energy resources from the eastern regions [2, 6, 12, 13, estimates by authors]: oil - from 69 million $\mathrm{t}$ in 2016 to $75-80$ million $\mathrm{t}$ in 2030; natural gas - from 15 billion $\mathrm{m}^{3}$ in 2016 to $50-60$ billion $\mathrm{m}^{3}$ in 2030; coal - from 70 million $\mathrm{t}$ in 2016 to $75-85$ million $\mathrm{t}$ in 2030; electricity - from 3.6 billion $\mathrm{kWh}$ in 2016 to $45-50$ billion $\mathrm{kWh}$ in 2030.

Current state and prospects for energy development in the East of Russia (for two scenarios) are given in Table 1.

The energy development in East Siberia and the Far East up to years 2030-2035 requires huge investment: the cost for some of the forecast strategies of energy development in the east of Russia is estimated [6] at \$200-250 billion only for new energy enterprises, including $\$ 80-85$ billion to be invested in the development of oil and gas production, and main oil and gas pipelines.

Such a strategy of energy development in East Siberia and the Far East is unlikely to be implemented without attraction of foreign investment, which supposes close energy cooperation between Russia and NEA countries.

The Russian government, regional authorities and companies have started a large-scale development of energy resources in the East of the country.

At present, the material resources of the eastern vector of Russia's energy policy are based on several large fuel and energy projects aimed at markets of NEA countries:

First, construction of the oil pipeline "East Siberia - Pacific Ocean" with a capacity of 80 million $t$ per year with an oil pipeline branch to Skovorodino towards China with a capacity up to 15-20 million $t$ of oil per year. 
Table 1. Production of energy resources in the East of the Russian Federation

\begin{tabular}{|l|c|c|c|}
\hline \multicolumn{1}{|c|}{ Index } & $\begin{array}{c}2015 \\
\text { (actual) }\end{array}$ & 2025 & 2035 \\
\cline { 3 - 4 } & 246 & $360-405$ & $420-475$ \\
\hline $\begin{array}{l}\text { Energy production, million tce, } \\
\text { total }\end{array}$ & & & \\
\hline including: & & & $230-260$ \\
\hline - East Siberia & 151 & $190-215$ & $190-215$ \\
\hline - Far East & 95 & $170-190$ & $100-110$ \\
\hline Oil, million ton, total & 63 & $85-95$ & $55-60$ \\
\hline - East Siberia & 37 & $45-50$ & $45-50$ \\
\hline - Far East & 26 & $40-45$ & $115-135$ \\
\hline $\begin{array}{l}\text { Natural gas, billion cubic meter, } \\
\text { total }\end{array}$ & 30 & $95-115$ & $50-60$ \\
\hline - East Siberia & 8 & $35-45$ & $65-75$ \\
\hline - Far East & 22 & $60-70$ & $170-190$ \\
\hline Coal, million ton, total & 136 & $153-165$ & $105-115$ \\
\hline - East Siberia & 96 & $90-100$ & $65-75$ \\
\hline - Far East & 40 & $63-65$ & $151-157$ \\
\hline Hydropower, TWh, total & 106 & $130-136$ & $118-122$ \\
\hline - East Siberia & 91 & $110-112$ & $33-35$ \\
\hline - Far East & 15 & $20-24$ & \\
\hline N & & & Forecast \\
\hline
\end{tabular}

Note: the left-hand value of the interval corresponds to an index for the conservative energy

development scenario, and the right-hand value - for the optimistic scenario

Source: forecast indices - estimates by authors

Second, "Gazprom" drew up a program to develop natural gas resources in the East of Russia, convert Russian regions to gas, and deliver natural gas to NEA countries.

Third, Russian electricity companies are conducting a feasibility study on large-scale electricity supply to China, Japan and other NEA countries.

Third, Russian electricity companies are conducting a feasibility study on large-scale electricity supply to China, Japan and other NEA countries.

For Russia facing the new global and regional challenges, it is principally important not only to cooperate with NEA countries and trade in energy resources, but also to pursue an active technology and innovation policy.

\section{Priority directions of technology and innovation cooperation between Russia and NEA countries in the field of energy}

\subsection{Participation in the construction of new Russian oil and gas-chemical clusters and their joint control.}

Oil and gas cooperation between Russia and NEA countries should take into consideration the following factors.

1. Currently, Russia at all levels is well aware of the need to deliver not only hydrocarbon raw materials to the international markets but also the products of advanced processing, with high value added. To this end, it is proposed to increase the production of oil products in the eastern regions of Russia, create new industries (oil-gas chemical, for example), since there is a high demand for their products in Russia and Northeast Asian countries. In the future Russia can become the major exporter of polymers in the region.

2. Oil and gas fields of the Siberian platform are unique in helium and ethane content. Natural gas from the fields of the Siberian platform contains up to $0.3-0.5 \%$ of helium and 
4.6-7.2 \% of ethane. Helium reserves (category $\mathrm{C}_{1}+\mathrm{C}_{2}$ ) from the oil and gas fields of the Siberian platform are estimated at 8.5 billion $\mathrm{m}^{3}$, or about $30 \%$ of the world reserves.

In the future, Russia can become the largest helium exporter.

Ministry of Energy of Russia devised a plan for the oil and gas chemistry development in Russia until 2030. This plan was approved by the Governmental Commission on the Fuel and Energy Complex on 28.12.2011, and its implementation (stage II) [14] was approved by the Order of Ministry of Energy of Russia No.79 of March 01, 2012.

The plan envisages the creation of 6 new oil and gas chemical clusters in Russia by 2030:

- Northwestern

- Caspian

- Volga

- West-Siberian

- East-Siberian

- Far-Eastern.

Russia is interested in mutually beneficial cooperation with foreign companies to establish new oil and gas chemical clusters in the East of the country, and in joint sale of produced polymers in the Russian and foreign markets.

\subsection{Participation in the interstate power interconnections in NEA}

\section{(1) A general view on the problem}

The interstate integration and cooperation between Russia and NEA countries in the field of electric power industry are the components of the Eastern energy strategy of the Russian Federation.

This cooperation suggests the development of interstate power interconnections between eastern regions of Russia and NEA countries.

This concerns a potential interconnection of power systems of Russia's East (East Siberia and the Far East), Mongolia, Chinese People's Republic, North Korea, South Korea and Japan for parallel operation.

The area served by such an interstate power super grid can contain various types of power plants (thermal, hydro, nuclear, wind, etc.) with a total installed capacity above 500 million $\mathrm{kW}$.

(2) Interstate power interconnection in NEA: prospects for Russia

The electric power potential of East Siberia and the Far East is great. These regions have above $20 \%$ of the installed capacity of all power plants in Russia. The electric power export potential of eastern regions that can be realized in the near future according to different estimations makes up 10-15 million $\mathrm{kW}$, including 6-7 million $\mathrm{kW}$ in East Siberia and 4-8 million $\mathrm{kW}$ in the Far East.

The calculations show that the reconstruction of existing power plants, completion of started construction of power plants, and commissioning of those planned for construction in the near future in East Siberia alone will provide a large amount of surplus power (according to various estimations from 30 to $40 \mathrm{TWh}$ ).

Such an amount of electric power can be transmitted by high voltage transmission lines in southeastern direction (Mongolia, China), and to Russia's Far East. Construction of the high voltage transmission line "East Siberia - Far East" will make it possible to integrate the interconnected power systems of Siberia and the Far East for parallel operation, which will enhance the reliability of power supply to consumers in these regions and create necessary preconditions for the construction of an Eastern "wing" of global electric power system [15, 16].

Currently, Russian companies are studying the possibility of constructing export-oriented power plants and high voltage transmission lines in the territory of Russia jointly with foreign 
companies to export a large amount of power (60-70 billion $\mathrm{kWh}$ ) to the Republic of Korea, and 25-30 billion $\mathrm{kWh}$ - to Japan. Russia and China can actively and fruitfully cooperate with Mongolia to build the interstate electric power system "Russia - Mongolia - China" [17].

Russian load serving entities, research and design institutes are actively participating in the development of the Asian Super Grid concept [18].

Russia can actively and effectively cooperate with Mongolia in the construction of Gobitec and use of its solar and wind potential to build Asian Super Grid [19].

\subsection{Innovation and technology cooperation in the field of coal Cooperation in advanced processing of brown coal}

A promising direction in the innovation and technology cooperation between Russia and NEA countries in the field of coal industry is the establishment of joint ventures for complex, advanced processing of Russian brown coals and the creation of a new industry in the east of Russia in the form of coal chemical production clusters.

Brown coal reserves in East Siberia and the Far East make up more than 85 billion $t$ [20]. The major brown coal deposits include:

- The deposits of Kansk-Achinsk basin in Krasnoyarsk Territory;

- $\quad$ The Svobodninskoye and Sergeyevskoye deposits in Amur Region;

- $\quad$ The Kangalasskoye deposit - in the Republic of Sakha (Yakutia);

- $\quad$ The Ushumskoye - in the Jewish Autonomous Region;

- $\quad$ The Mukhinskoye - in Khabarovsk Territory;

- $\quad$ The Solntsevskoye - in Sakhalin Region.

The cost of coal production is relatively low, therefore, these deposits can be used to set up joint ventures with foreign companies, that will be involved in the advanced processing of brown coal.

The products of advanced coal processing (such as motor fuel) can be supplied to consumers in Russia and other countries.

\subsection{Cooperation in reliable power supply to off-grid and hard-to-access consumers in the eastern regions of Russia through the construction of renewable energy sources}

According to the draft Russia's energy strategy 2035 [21], it is planned to place into service a great amount of renewable energy sources throughout this period. The projected increase in the share of renewable energy sources in the total electricity generation makes up from current $0.2 \%$ to $3 \%$ in 2035 . This is particularly important for the economy of the eastern regions.

The use of renewable energy sources (mini-HPP, Geo-TPP, solar and wind power plants) is a strategic priority in the energy development of northern and hard-to access territories of Russia's East.

We estimate the total renewable capacity to be placed into service in the off-grid areas and the areas with unstable power supply in the east of Russia at 600-870 MW until 2035 according to the base and moderate-optimistic scenarios, respectively [2]. The main share of renewable capacity to be commissioned in East Siberia falls on solar power plants (287-318 MW). The main share of capacities to be put into operation in the Far East is represented by wind turbines (84-155 MW) (Fig.1). 


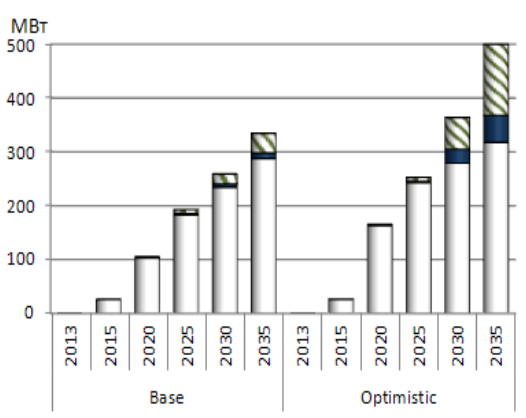

a) East Siberia

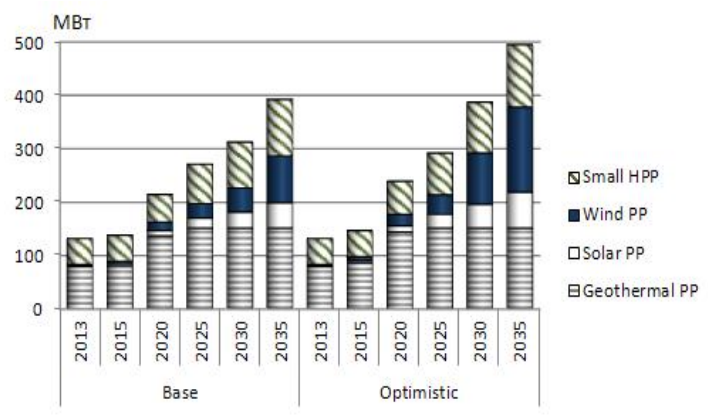

b)Far East

Fig.1. Dynamics of installed renewable capacities

The total installed capacity of renewable energy sources in the eastern regions will rise by 5.5-7.5 times by 2035 and will make up 727-1000 MW including solar power plants 335-385 MW and wind power plants -100-210 MW.

The Kamchatka Territory, Kuril islands of the Sakhalin Region, arctic coast of Krasnoyarsk Territory and the Republic of Sakha (Yakutia), Eastern part of the Magadan Region, Khabarovsk and Primorie Territories, and Northeast of Chukot Autonomous Area are the most promising for the development of wind power industry in Russia's East.

The priority areas for the development of solar power are the territories of the Republics of Buryatia, Tyva, Khakassia, Sakha (Yakutia); Transbaikal Territory; and southern areas of Irkutsk and Amur Regions.

The beneficial cooperation with foreign companies can be expected in the field of construction of renewable energy sources and establishment of joint ventures in the eastern regions of Russia.

The projects for construction of wind power plants in the settlement of Ust-Kamchatsk of Kamchatka Territory and settlement of Tiksi of the Republic of Sakha (Yakutia) with the Japanese companies Komaihaltec Inc. and MITSUI \& Co. Ltd can serve as an example of such cooperation.

\section{Conclusions}

1. Implementation of Russia's Eastern energy strategy is a challenging task. This challenge lies in the complexity of the task, which is carried out on a vast territory, and involves a great number of participants from different countries. Moreover, the policy measures (especially interstate energy projects) that suggest tight international energy cooperation at the federal (state), regional and interregional levels are very capital intensive.

2. There is an urgent necessity to develop a scientifically grounded strategy (road map) of energy cooperation between Russia and NEA countries, which should show the order of energy resources development, sequence and time of their supply to domestic consumers, amounts of export and import deliveries. The strategy should assess socioeconomic and other consequences from specific interstate projects not only for the individual companies, but also for the regions and an entire country.

3. To promote mutually beneficial forms of energy cooperation between Russia and NEA countries it is necessary to meet at least the following five conditions:

1) There should be political will and serious intentions of participants to implement a specific energy project mutually beneficial for each country. 
2) The economic and energy policy of central and regional authorities, and business community of the countries should be coordinated to develop interstate energy projects.

3) The consequences (effects) of the large-scale interstate energy projects for countries, regions and energy companies should be comprehensively assessed, considering high uncertainty of future development, economic risks and global challenges.

4) The mutually acceptable mechanisms (organizational, economic, legal and other) should be developed to implement interstate energy projects.

5) The interstate projects should be developed and done by an international team (in all the stages: from feasibility study and design works to their implementation).

\section{References}

1. Russia's energy strategy 2020, (approved by the resolution of the Government of RF No. 1234-p of August 28, 2003). 118 p., Moscow (September 2003)

2. Russia's energy strategy 2030 (approved by the resolution of the Government of RF No.1715-p of November 13 2009). http://www.energystrategy.ru/projects/es-2030.htm

3. Program for creation of unified gas production, transportation and supply system in East Siberia and the Far East, considering potential gas export to the markets of China and other APR countries (approved by the order No. 340 of Ministry of Industry and Energy of RF of 03.09.2007).

4. Strategy for socioeconomic development of the Far East and Baikal region 2025 (approved by the resolution of the Government of RF No.2094-p of December 28,2009)

http://www.minregion.ru/activities/territorial_planning/strategy/federal_development/3 $46 /$

5. Strategy of socioeconomic development of Siberia 2020 (approved by the resolution of the Government of RF No.1120-p of July 5 2010).

6. Eastern vector of Russia's energy strategy: current state, look into the future. Ed. by N.I.Voropai, B.G.Saneev. Novosibirsk: Academic Publishing House "Geo",368 p. (2011)

7. Fuel and energy complex of the Sakhalin region: current state and development prospects /Ed. by B.G.Saneev, V.N.Tikhonkikh. Moscow: Publishing House "Energia", 240 p. (2010)

8. Fuel and energy complex of the Amur region: current state and development prospects /Ed.by B.G. Saneev, V.E.Peskov. Moscow: Publishing House "Energia”, 240 p. (2010)

9. Energy strategy of the Republic of Sakha (Yakutia) 2030 /Ed. by G.F.Alekseyev, V.I.Kondratieva, A.A.Struchkov, N.A.Petrov, B.G.Saneev, A.F.Safronov. YakutskIrkutsk: Media-Holding "Yakutia", 328 p. (2010)

10. Fuel and energy complex of the Irkutsk region. Current state, development prospects / Ed. by B.G.Saneev, P.A.Voronin. Moscow: Publishing House "Energia", 230 p. (2013)

11. Energy sector of the Baikal region: current state, prospects, development strategy /Ed. by B.G. Saneev. Novosibirsk: Academic Publishing House "Geo", 176 p. (2015)

12. A.A.Makarov, N.I.Voropai, V.V.Saenko, Saneev B.G., et al. Regional features of fuel and energy complex // in the book "Russia's energy: look into the future". Materials for the energy strategy of Russia 2030 /Ed. by A.B.Yanovsky et al. M. Publishing House "Energiya", p.435-460. (2010)

13. B.Saneev, D.Sokolov Russian energy development in Eastern Siberia and the Far East and relations with East Asian countries in the energy sector / Russia and East Asia. 
Informal and gradual integration / Ed. by Tsuneo Araha and Anna Vassilieva, p. 181199. (2014)

14. Plan for the development of gas and petro chemistry in Russia until 2030 (stage II), approved by the order of the Ministry of Energy of Russia No.79, (March 1, 2012).

15. N.I.Voropai, V.V.Ershevich, Y.N. Rudenko Development of international power interconnections - a way to the creation of global electric power system. Irkutsk: SEI SB RAS, 29 p. (preprint) (1995)

16. L.S.Belyaev, S.V.Podkovalnikov, V.A.Saveliev, L.Y.Chudinova. Effectiveness of interstate electric ties. Novosibirsk: Nauka, 239 p. (2008)

17. N.I.Voropai, B.G.Saneev, S.Batkhuyag, Kh.Enkhjargal. Energy cooperation between Mongolia and Russia: current state and strategic directions. Khabarovsk: Spatial economics, No.3, p.108-122. (2013)

18. V N.I.oropai, S.V.Podkovalnikov, B.G.Saneev. Interstate cooperation in Northeast Asia: state, potential projects, energy infrastructure. Moscow: Energy policy, No.2, p.55-64. (2014)

19. Gobitec and Asian Supergrid for Renewable Energies in Northeast Asia / S. Mano, B. Ovgor, Z. Samadov, D. Sokolov, B. Saneev, etc. Brussels, 110 p. (2014)

20. Program for the coal industry development in Russia 2030 /Ministry of Energy of the Russian Federation, Moscow, 178 p. (2014)

21. Draft energy strategy of the Russian Federation 2035 (edition of 01.02.2017) /Ministry of Energy of Russia, 78 p.

22. B.G.Saneev, I.Yu.Ivanova, T.F.Tuguzova. Development of renewable energy in Russia's East in the first half of the 21st century against the background of the nationwide trends. Energy policy, Iss.3, p.66-73. (2016) 